\title{
A NEW SLOVAKIAN-HUNGARIAN CROSS-BORDER GEOPARK IN CENTRAL EUROPE - POSSIBILITY FOR PROMOTING BETTER CONNECTIONS BETWEEN THE TWO COUNTRIES
}

\author{
Gergely Horváth ${ }^{1}$, Gábor Csüllög ${ }^{2}$
}

Received 31 December 2012; Accepted 17 May 2013

\begin{abstract}
In the past years, many geoparks have been established all over the world, based mainly on the geoheritage, and partly on the cultural heritage, of the regions. Their main aim is to promote the spatial development of certain regions, especially by the development of tourism, including geo- and ecotourism. One of the newest geoparks is the Novohrad-Nógrád Geopark along the border of Slovakia and Hungary, which, having a high status, belongs to the UNESCO Global Geoparks Network. What is remarkable about it is that it was the very first cross-border geopark. Because of historical elements and due to political intentions, borders often play a more disjunctive than connective role, and the changes of the borders in the $20^{\text {th }}$ century often distorted the spatial structure and turned former peripheries into flourishing regions. This was characteristic also of the regions where the Novohrad-Nógrád Geopark was established. Beyond the perspective for the spatial development of these regions, this cross-border geopark forces directly the local authorities and non-governmental organizations (NGOs) on both sides of the border to maintain tighter contacts for co-operation, promoting by this means also better connections between the two countries.
\end{abstract}

Keywords: border, cross-border co-operation, geopark, geotourism, geosites, cultural sites, spatial development, Novohrad, Nógrád

Összefoglalás: Az elmúlt években a Földön sokfelé alapítottak geoparkokat az adott térségek földtudományi és részben kulturális értékeire építve. A fö cél a régiók területfejlesztésének elősegítése, elsősorban a turizmus - leginkább az öko- és geoturizmus - fejlesztése révén. A geoparkok közül az egyik legújabb a Magyarország és Szlovákia határa mentén kialakított Novohrad-Nógrád Geopark, amely tagja az UNESCO Global Geoparks Network hálózatnak. Különlegessége, hogy ez a Föld első határokon átívelő geoparkja. Történelmi okok és politikai szándékok miatt a határok sajnos gyakrabban játszottak elválasztó, mintsem

\footnotetext{
1 Gergely Horváth PhD., college professor, Department of Landscape and Environmental Geography Institute of Geography and Geosciences Eötvös Loránd University Pázmány sétány 1/C H-1117 Budapest; e-mail: horvger@caesar.elte.hu

${ }^{2}$ Gábor Csüllög PhD., lecturer, Department of Landscape and Environmental Geography Institute of Geography and Geosciences Eötvös Loránd University Pázmány sétány 1/C H-1117 Budapest; e-mail: g.csullog@gmail.com
} 
összekötő szerepet, a 20. századi határváltozások pedig gyakran eltorzították a korábbi századok alatt kialakult térszerkezetet és hanyatló perifériákká tettek korábban virágzó régiókat. Jellemzi ez azokat a régiókat is, ahol a NógrádNovohrad Geoparkot megalapították. A határon átívelő geopark megalapítása a régiók területfejlesztési lehetőségein túl azért is elönyös, mert ösztönzi az önkormányzatokat, a helyi irányító szerveket és a civil szervezeteket a határ mindkét oldalán arra, hogy szorosabbra fonják együttmüködésüket, elösegítve ezzel a két ország közötti kapcsolatok javulását is.

\section{Introduction: Changing role and problems of the borders in Central Europe}

Borders in Central Europe - this has been one of the severest problems for many years: taking into consideration how dominant role played the frequent changes of the borders in the transformation of the Central European spatial structure during centuries. Especially in the last hundred years, due to political intentions, the borders got unfortunately a primarily disjunctive role; the new borders within the disrupted, formerly uniform, spatial structure often distorted the spatial structure lines and the hinterland of regional centres as a result, making peripheries from formerly flourishing regions (Csüllög 2003). Moreover, borders often represented European fault lines, too, contributing to tragic, destructive wars in the first half of the $20^{\text {th }}$ century. From 1945-1989 the disjunctive or connecting link of the borders depended on political points of view, however, and they were much more often disjunctive, in many cases practically impassable. Citizens of Central European countries still remember how humiliating it was to cross the Austro-Hungarian border, even more so the one between Hungary and Romania, although the latter belonged to the same political bloc. This undesirable situation could have radically changed after the political turn at the beginning of the '90s of the last century, and especially later due to the connection of the Central European countries to the European Union. It is a great disappointment that although political and ideological barriers recently do not restrict passing the borders, also nowadays the borders are more or less rather disjunctive than connecting.

Studying the situation along the borders in Central Europe, some common characteristic elements can be observed, and it can be stated that the recent situation has negative and promising factors alike. The worst factors are, among others, that the regions along the borders became peripheries; the living standards are often much lower than in other regions; the age demographics are very inefficient, young people migrate to developed regions; and the capital investments are deficient (and - due to global crisis - still getting fewer), especially joint investments are rare (Csüllög 2002). There are some promising factors as well: e.g., crossborder co-operations came into being, especially in the fields of logistics, research \& development, and commerce, and the improvements of the infrastructure, especially along the transit corridors, are in progress (however, only to a certain extent). 


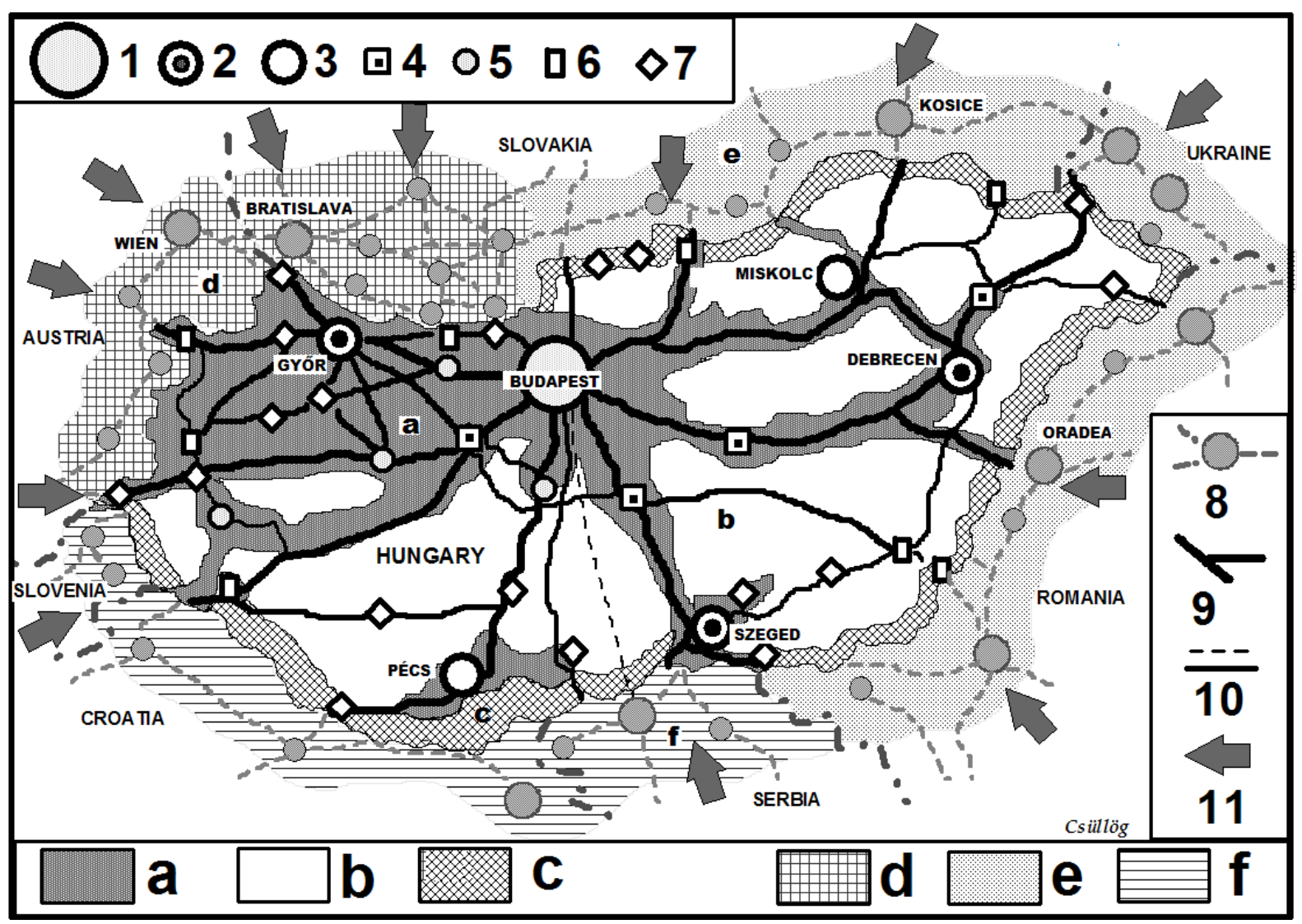

Fig 1. Spatial structure of the borders of Hungary and her neighbouring countries (ed. Csüllög, G.). Legend: 1. National centre, 2. Regional centre with direct cross-border-effect zone, 3. Regional centre with indirect over-theborder effect zone, 4. National distributors of transit drift, 5. Partial centres of transit drift, 6. Near-border centres of transit and local border drift, 7. Background centres, 8. External near-border centres with spatial structure lines, 9. Major national spatial structure and spatial transit lines, 10. Secondary spatial structure and spatial transit lines, 11. The arrival directions of transit drifts: a) Developed spatial structure with dense city network, active transit with national and regional spatial drift lines; b) Limited spatial structure without significant spatial organising centres and transit lines; c) Passive border zones without centres and near-border transit lines; d) Spatial structure favourable for cross-border connections on both sides; e) Mainly the external spatial structure favourable for cross-border connections, only the transit drifts are of proper activity; f) Spatial structure deficient for cross-border connections on both sides.

In addition, it can be stated that on both sides of the borders similar structural problems arise, and it would be very important and necessary to find breaking points. There are some important tools, which can promote this breakthrough. Among others, establishing simple, direct frontier connections of settlements or micro-regions can ensure mutual advantages; the freer flow of labour, mainly the ability to be employed in the other country or region close to the border can help to stop migration to far-away lands etc. For ending the disadvantageous position, cooperation on all possible manners, joint applying for funds, and especially co-operation of nearby regional centres on the two sides of the border would be more and more important. Today, it is not only the pressures of interdependence, but also the opportunity to use the advantages deriving from certain European processes that puts a more favourable light on the advantages of the mutually-formed frontier spatial structure. The more effective the crossborder activities are, the more quickly these disadvantaged regions can develop. 


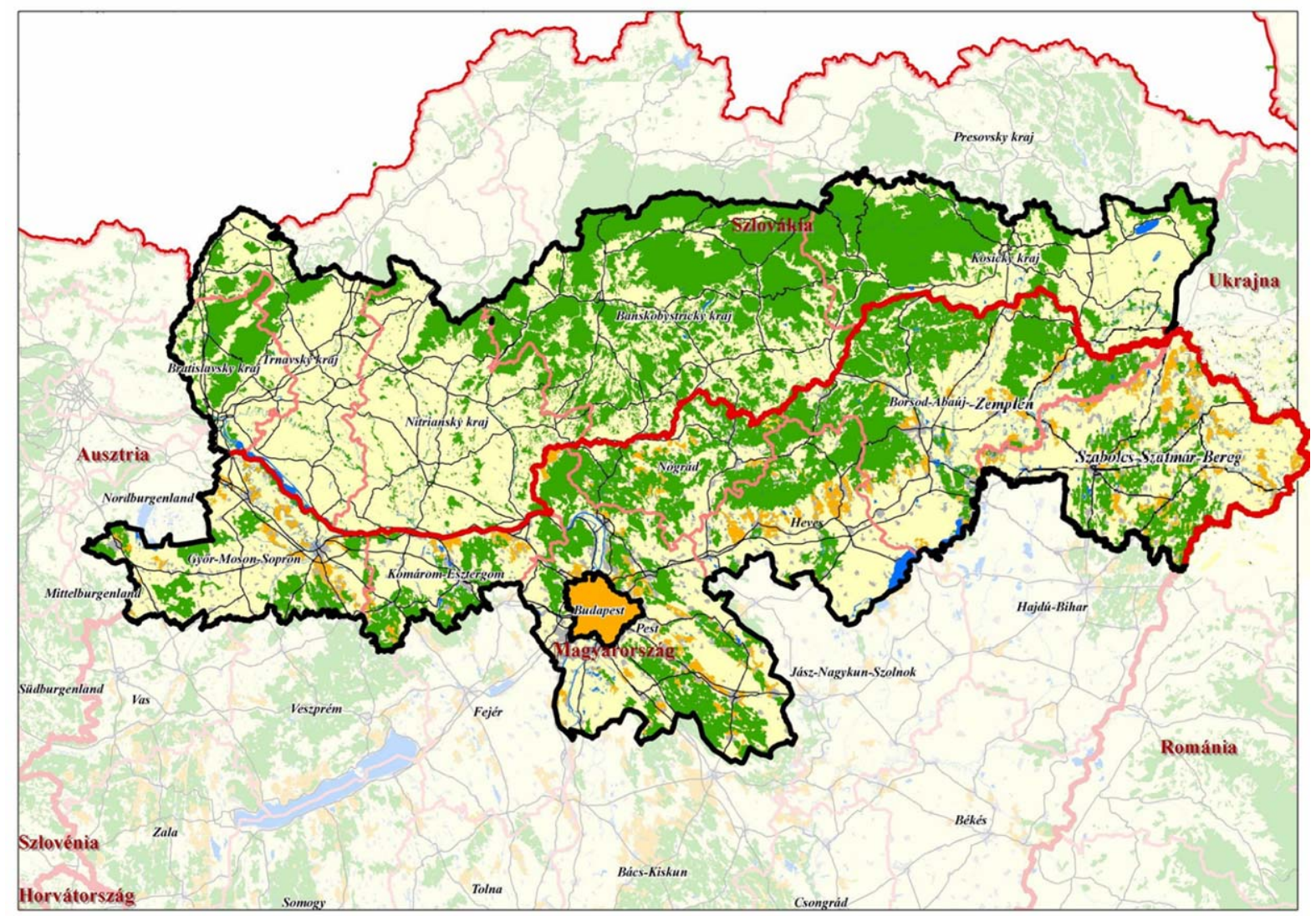

Fig 2. The Hungarian-Slovakian borderland. Source: www.husk-cbc.eu/hu/a_regiorol .

Similar problems can be observed in the case of Hungary. However, because of historical, political and economic factors, the borders - and also the micro-regions close to the borders have a different state of affairs within the Hungarian spatial structure. Along some sections of the borderline, the spatial structure is favourable for cross-border connections on both sides; along other sections mainly the external spatial structure is favourable for cross-border connections, and mostly the transit drifts are of proper activity; and, finally, along further sections the spatial structure is deficient for cross-border connections on both sides (Figure 1). The functional change of borders - including the strengthening of connecting roles - does not occur along the whole border, moreover, due to the fact that differences in spatial structure and economic development appear (Csüllög 2008). E.g., a joined impact area with good connections is the region close to Austrian-Slovakian-Hungarian triple border between Szombathely and Esztergom, encompassing the macro-regions of Sopron and Györ, where the function alteration and the developed spatial structure strengthen each other. These sections of borderlines can be characterised as developed external impact areas of the same level of development with centres of external macro-regions (Wien, Bratislava), having a strong cross-border effect (tight local contacts). In opposition, there are regions with poorer contact -e.g., from Esztergom to Sátoraljaújhely along the border between Hungary and Slovakia-- which are passive border zones without centres and near-border transit lines. 


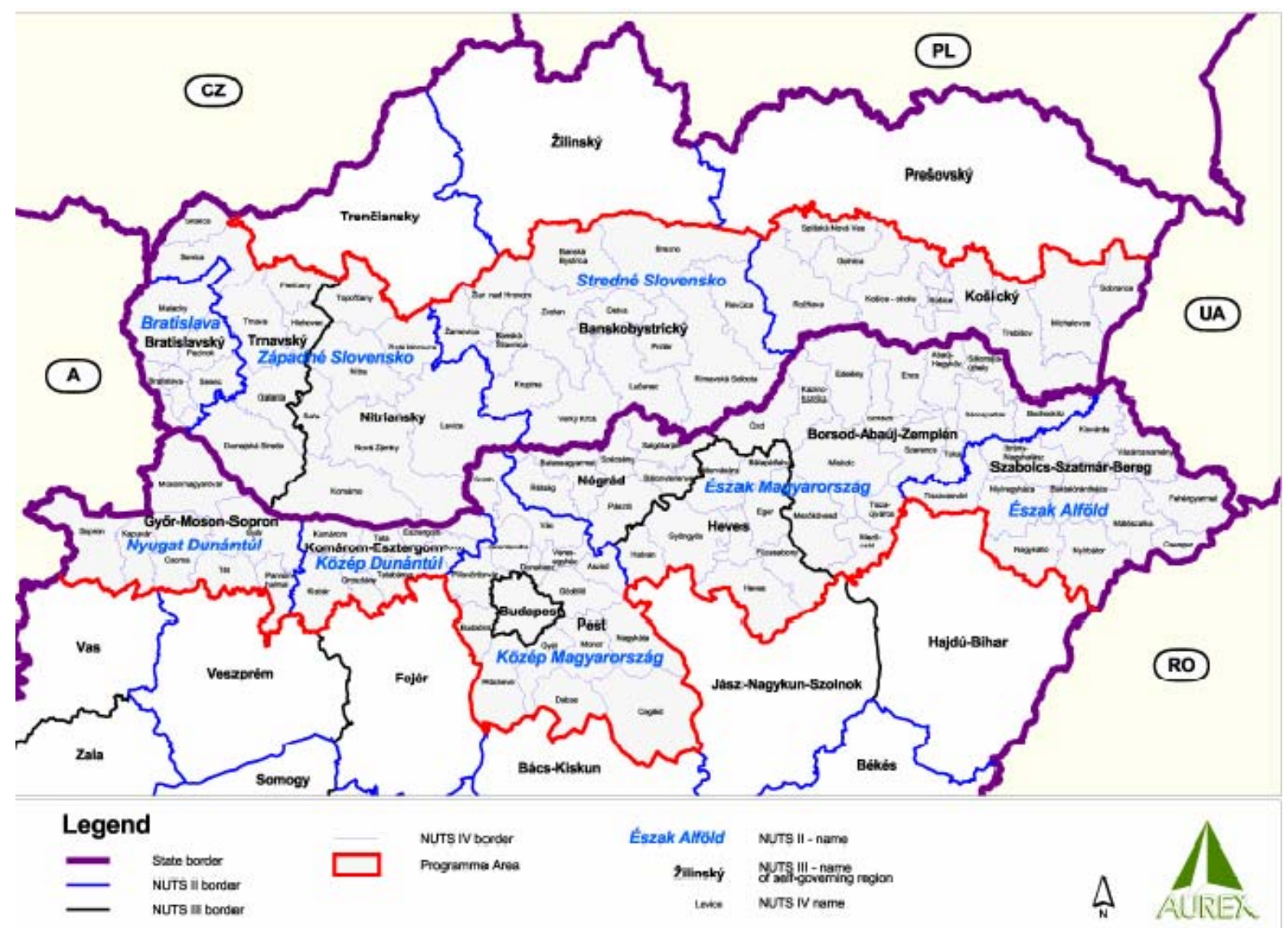

Fig 3. Territorial division of the Hungarian-Slovakian borderland. Source: Hungary-Slovakia cross-border co-operation programme 2007-2013. p. 124.

\section{Cross-border connections between Hungary and Slovakia}

The Eastern part of the Hungarian-Slovakian borderland (Figures 2 and 3) bears many symptoms of the above-mentioned dysfunctions. These areas are characterised by huge regional disparities, decreasing population (Figure 4), high unemployment rates (in some cases significantly higher than the respective national averages); in all, the economic structure of these regions requires transformation; service sectors should especially be increased, which consequently demands human-resource development. These regions suffer from insufficiently developed or even missing technical infrastructure (Figure 5) that affects the quality of life, the accessibility and the attractiveness of the border areas for tourists and investors. It is surprising - or just the contrary, typical - that the North-South stream lines of the traffic that really could connect the two countries are more undeveloped than the West-East ones in North Hungary and South Slovakia. It is important, nevertheless, to mention that the whole border section can be considered an ecological corridor between the two countries - although as Figure 6 indicates, there are several nature-protection areas in the Hungarian-Slovakian borderland - further developments should be accomplished also in the field of environmental protection. 


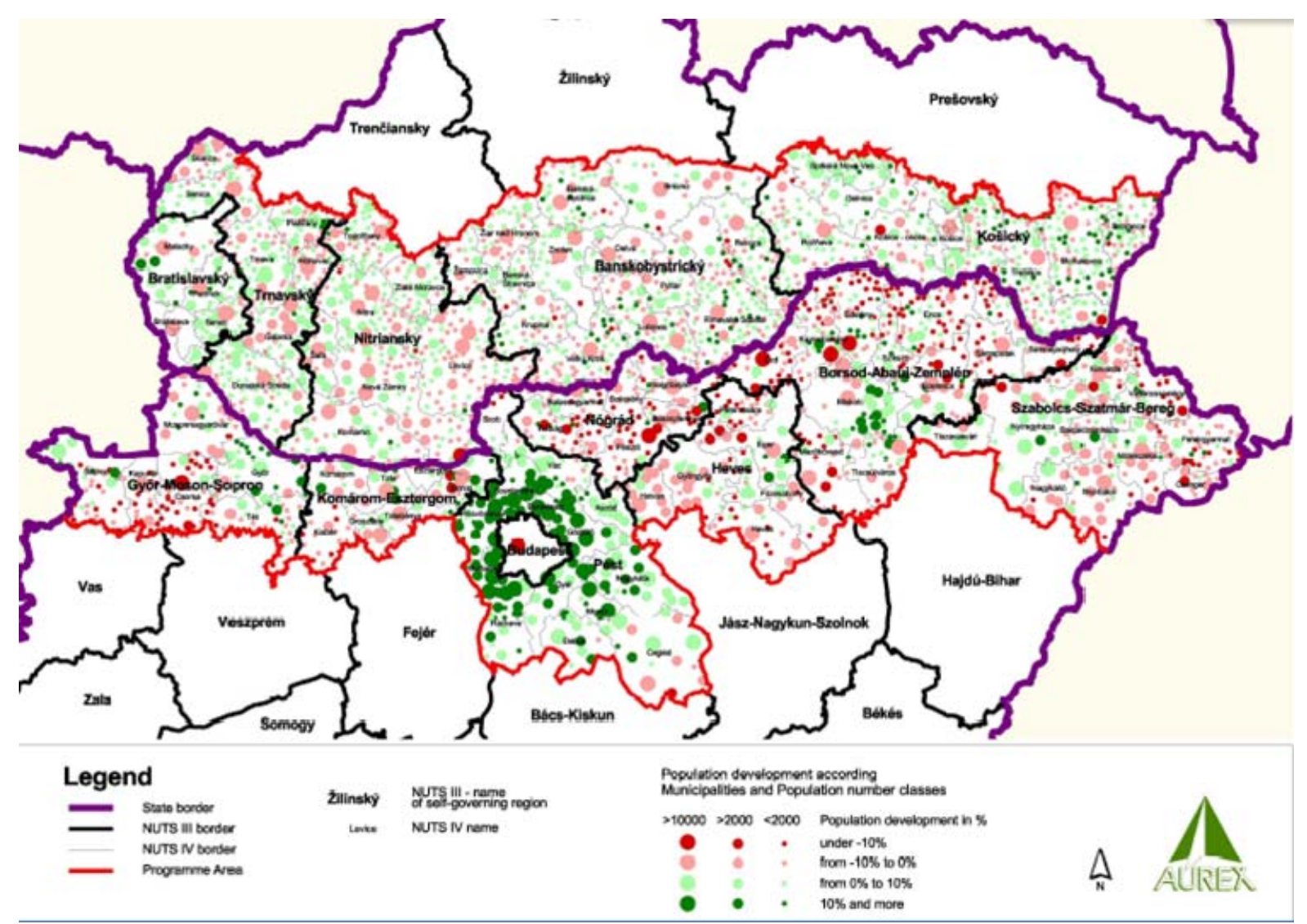

Fig 4. Population of the Hungarian-Slovakian borderland. Source: Hungary-Slovakia cross-border co-operation programme 2007-2013. p 125.

Therefore, to improve on these disadvantages, a 'Hungary-Slovakia Cross-border Co-operation Programme 2007-2013' was approved by the European Commission in 2007. The programme involves European Community support as part of the European Regional Development Fund (ERDF) for specific Hungarian and Slovak regions that lie along their common border (according to the administrative divisions 8 'counties' in Hungary and 5 'districts' in Slovakia belong to the beneficiaries). According to the decision, the programme is focusing on three main cooperation fields (Operational Programme 'Hungary-Slovak Republic'):

- the development of cross-border economic, social and environmental activities through joint strategies for a sustainable territorial development;

- strengthening transnational co-operations through actions related to Community priorities and promoting an integrated territorial development;

- the reinforcement of the effectiveness of the regional policy by promoting interregional cooperations through the exchange of experience at the appropriate territorial level.

The main impacts expected include improved cross-border connections; enhanced joint management of public services and resources; more business start-ups and tourism products; and local communities more motivated to engage in cross-border cooperation to improve the region's attractiveness. 


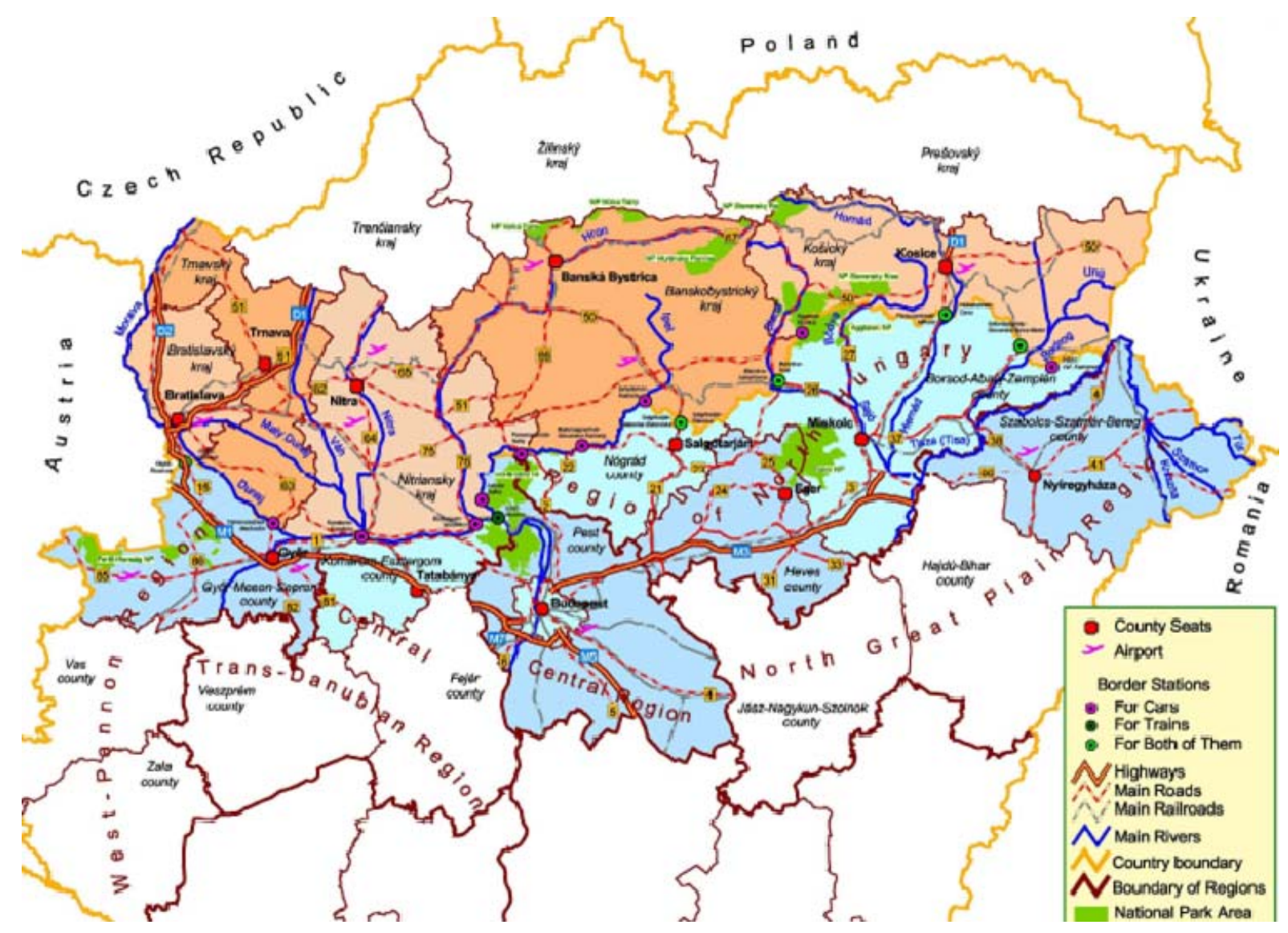

Fig 5. Transport in the Hungarian-Slovakian borderland. Source: Hungary-Slovakia cross-border co-operation programme 2007-2013. p. 126.

Among the priorities, 'Priority 2' encompasses "Environment, Nature Protection and Accessibility," aiming to encourage joint actions designed to protect the natural environment, focusing on development of the transport infrastructure (including road constructions, bordercrossing facilities across rivers, and public transport) and in communication infrastructure to improve information flows. It is important to mention that approximately $53 \%$ of the total funding can be appropriated for these purposes.

Looking for breaking points, these factors lead to the idea of establishing a common geopark.

\section{The aim and role of the geoparks}

The notion of a 'geopark' has only a very short past. It had been launched by UNESCO at the end of the 20th century. In 2000, the European Geopark Network was established as a new concept to satisfy the demands of a kind of regional development. According to the definition by UNESCO, 'a geopark is an area containing a number of protected geosites, which are part of an integrated concept of protection, education and sustainable development.' This definition contains four keywords: regional development, geoconservation, education and geotourism. The main aims and possibilities of establishing these are:

- to conserve significant geological features ('geosites') by protection measures in consultation with collaborating universities, geological surveys or relevant statutory bodies in accordance with local traditions and legislative obligations;

- to promote education: a geopark organizes activities and provides logistic support to communicate geoscientific knowledge and environmental concepts to the public;

- and to develop the geotourism: a geopark stimulates economic activity and sustainable development through geotourism and local socio-economic development through the promotion of a quality label linked with the local natural heritage. 


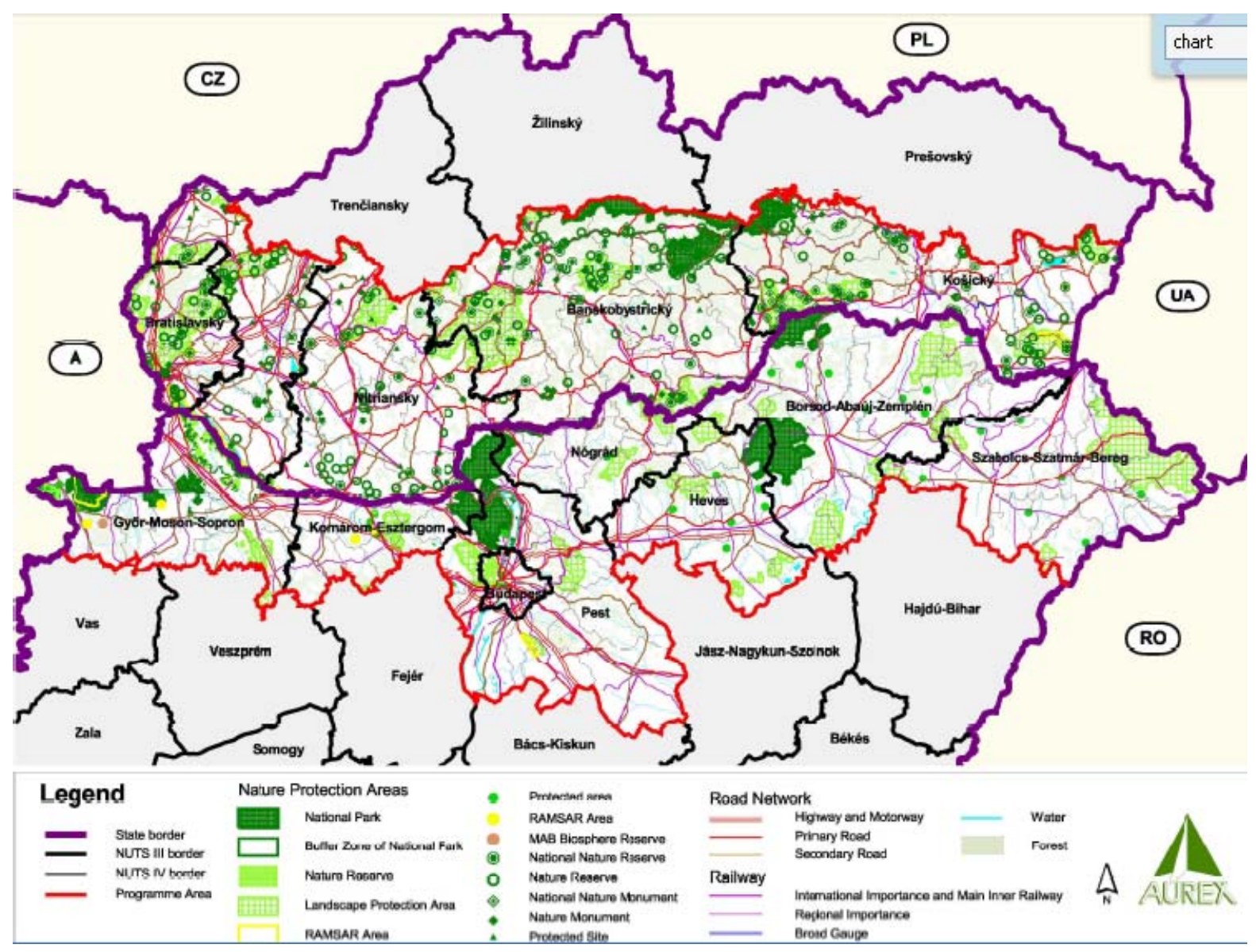

Fig 6. Nature preservation areas of the Hungarian-Slovakian borderland. Source: Hungary-Slovakia cross-border co -operation programme 2007-2013. p. 127.

The latter, the geotourism, is a very new notion, but it has promising prospects. According to Dowling \& Newsome (2006), geotourism is 'a form of natural area tourism that specifically focuses on geology and landscape' that has become very important and popular in recent times (Pralong 2006, Dowling 2011).

As it has been formulated in the Langkawi Declaration (2010), announced in the actual conference of the geopark movement: '...philosophy and vision of geoparks provide a balance between conservation of heritage, local socioeconomic development and local community empowerment. Thus, geopark is an effective and practical tool for regional sustainable development...' 


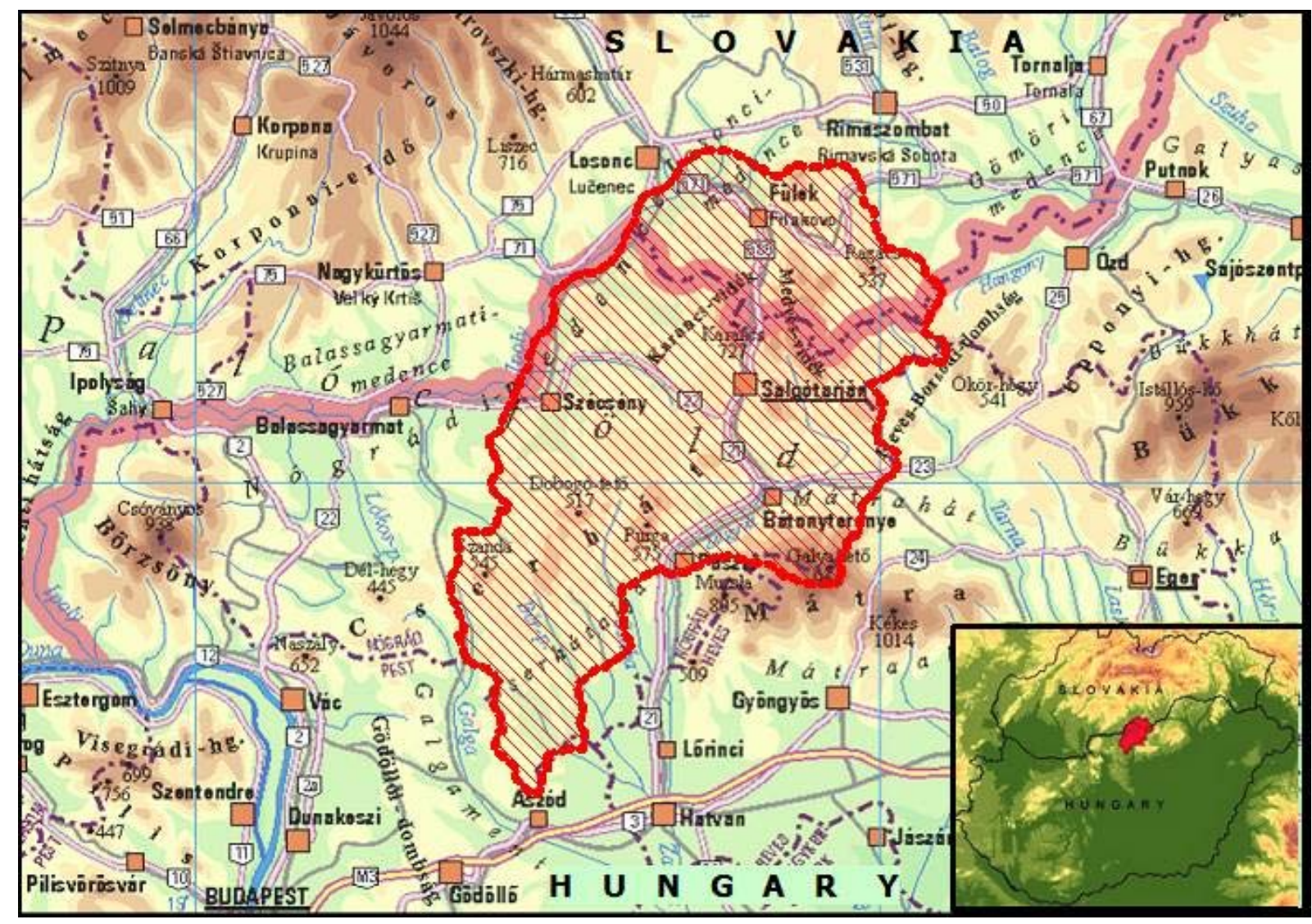

Fig 7. Location of the geopark (ed. Csüllög 2012).

The geopark-movement rapidly reached great success, and the geopark-idea became very popular due to its combination of conservation, sustainable development and community involvement. Therefore, year by year, more and more geoparks were established, and recently, in 2012 the so-called Global Geoparks Network has already 90 internationally accepted and registered members in 26 countries, and there are also several 'local' 'regional' (internationally not accepted) geoparks. The names of the newly accepted ones are proclaimed during the biennial international conferences of the geoparks. It is an important competition because the number of the candidates is increasing radically and the stipulations are rigorous (Guidelines and Criteria for National Geoparks, 2010). Aspiring geopark proposal submissions need long preparations and an enormous bulk of written materials, a dossier must be submitted containing location, surface area, geographical and human statistics, organization, scientific description (including the geology, geomorphology, geosites and their status) of the region, arguments for nominating the region as a European Geopark, etc.

\section{Geoheritage and cultural heritage of the Novohrad-Nógrád Geopark}

During the Fourth Global Geopark Conference in Langkawi (Malaysia) in 2010 a new geopark was born: the Novohrad-Nógrád Geopark. Its uniqueness is that it was the first cross-border, transnational geopark. Its area is $1,587 \mathrm{~km}^{2}$, from that $336 \mathrm{~km}^{2}$ belong to Slovakia and 1,251 $\mathrm{km}^{2}$ to Hungary. 


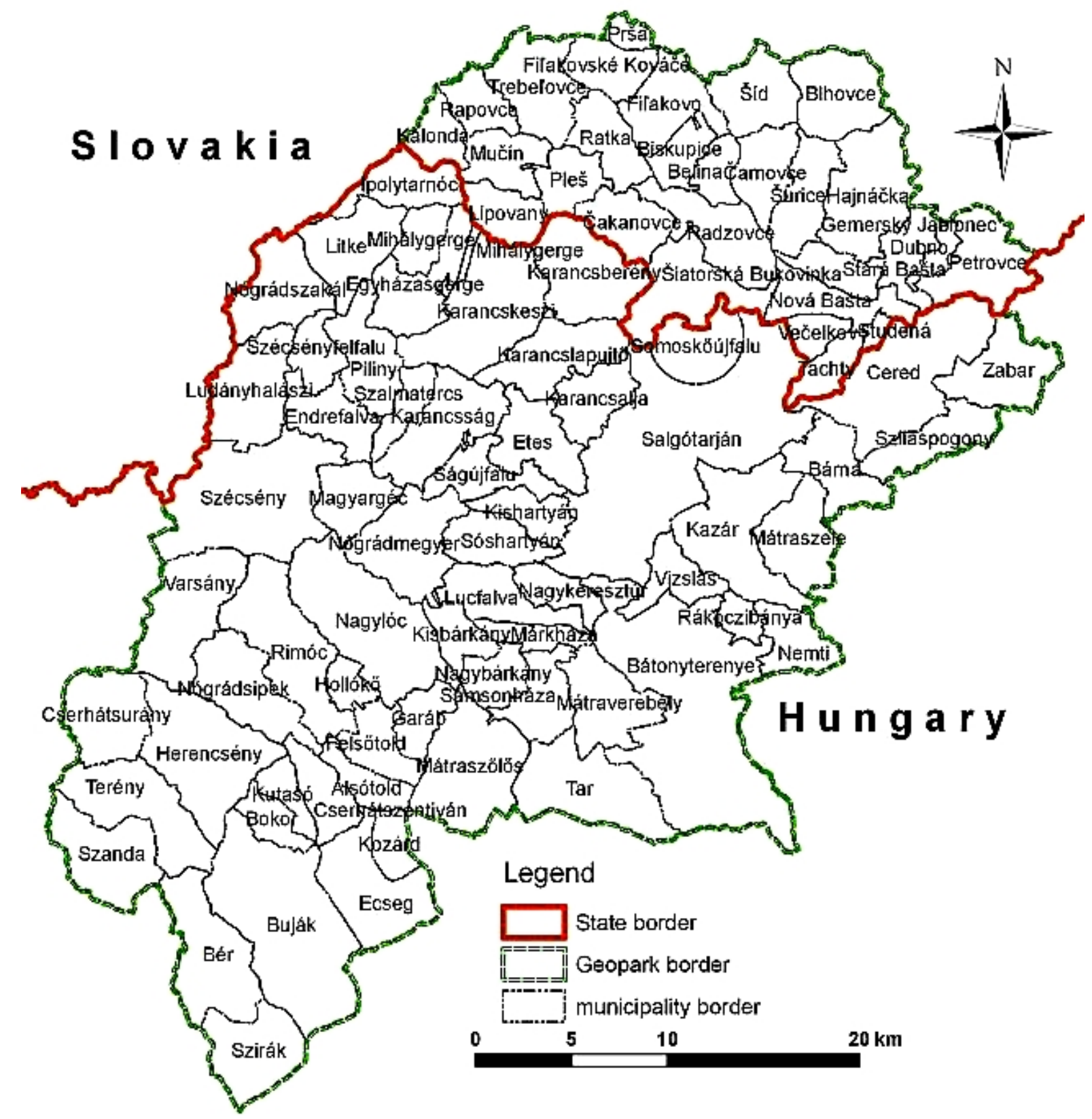

Fig 8. Settlements belonging to the Geopark. Source: Novohrad-Nógrád Geopark Master plan 2010-2015. p. 4.

The establishment of the geopark had long-lasting preliminaries. At the end of the 1990s, the directorates of the Bükk National Park (Hungary) and Protected Landscape Area (CHKO) Cerová vrchovina (Slovakia) planned a thematic route for introducing jointly the most interesting geosites. In 2001 a Phare CBC project ('Geological study trail in the CHKO Cerova vrchovina and Karancs-Medves LPA') was handed in, but unfortunately has not been accepted. In 2005 a new Phare CBC project was created, 'Preparing of Nógrád Geopark,' by Salgótarján Microregion. This application was successful, so the planning of the geopark could then begin. For the application, in 2008 experts of the Hungarian Geological Society made an inventory of the geosites, and in 2009-2010 - involving experts also from Slovakia - the total required dossier of the application has been worked out. 


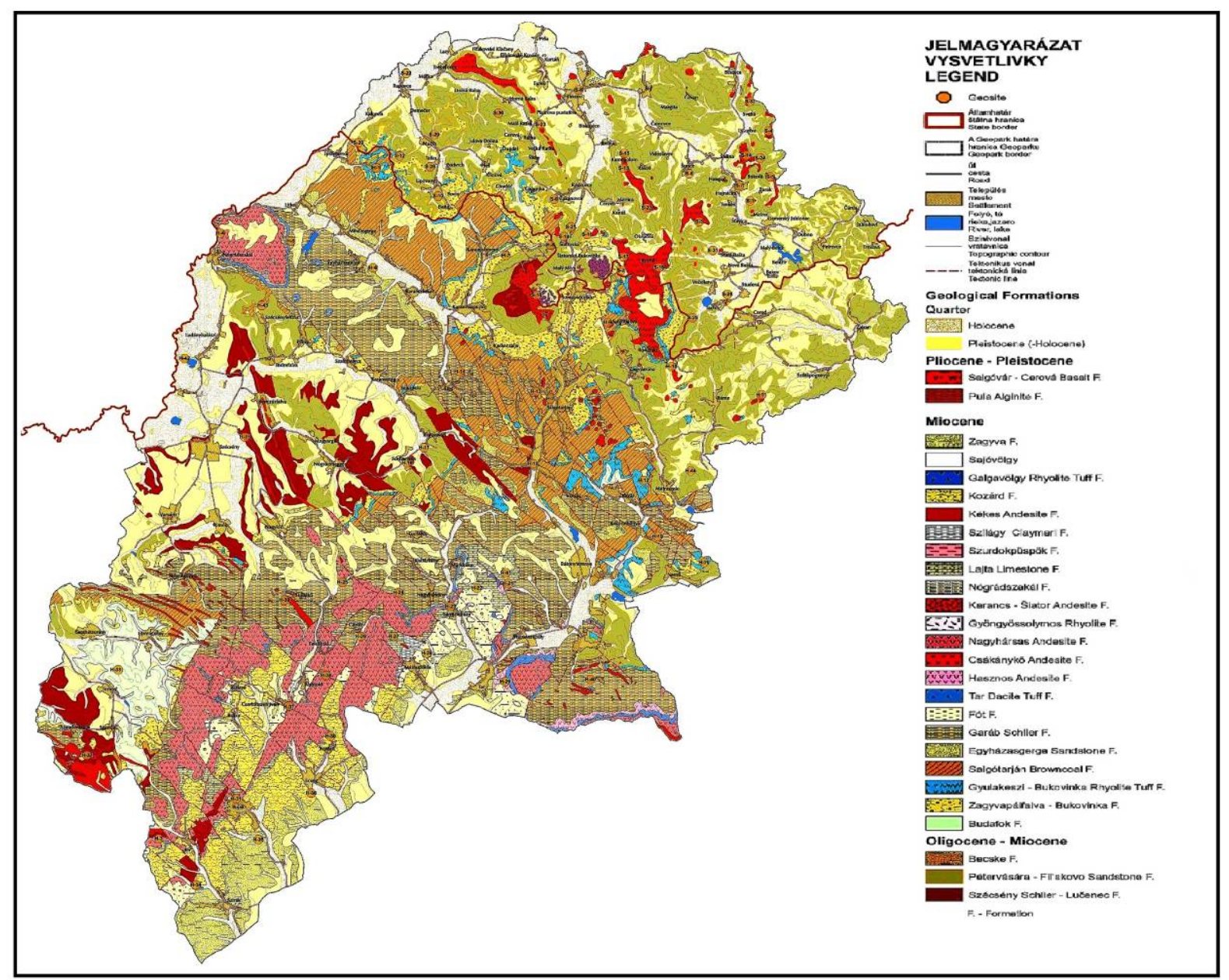

Fig 9. Geological map of the Novohrad-Nógrád Geopark (ed. Szarvas, I. 2011).

The geopark can be found along the southern ranges of the Northwest Carpathian Mountains, encompassing the Cserhát, Karancs, Medves and Cseres (Cerová) Mountains (Figure 7). The official area of the geopark belongs to 9 microregions, and embraces altogether 91 settlements, 63 in Hungary, 28 in Slovakia (Figure 8). The Slovak name (Novohrad) and the Hungarian name (Nógrád) has the same origin: it was the name of a former county in historic Hungary, which had been shared between Hungary and Slovakia after the First World War. The geopark extends over almost the exact area as the former county.

This region is really suitable for establishing a geopark because it possesses an outstanding geoheritage, in addition, also cultural, historical and architectural values. Of course, a geopark has to be based on geological heritage and on individual geosites (Cimermanová \& Anderková 2006, Szarvas 2009, Horváth \& Csüllög 2011). In the Novohrad-Nógrád Geopark the landscape is determined mainly by the diversity of rocks (Figure 9); it consists of Neogene and partly Palaeogene sediments (near-shore neritic sediments such as sandstone, clayey marl and schlieren are dominant), and Late Neogene and Early Quaternary volcanic rocks (rhyolites, andesites and basalts from different volcanic epochs). The dismembered relief is due to frequent tectonic movements, and the landscape is determined by a series of faulted, erosionally dissected, hilly ridges. Picking out only some especially valuable geosites, sandstone (Figure 10,11) and rhyolite tuff (Figure 12) formations, andesite dykes, and basalt formations like Somos-kő (Šomoška, Figure 13) Ajnács-kő (Hajnačka, Fig. 14) and Béna (Belina, Fig. 15) can be mentioned prominently. 


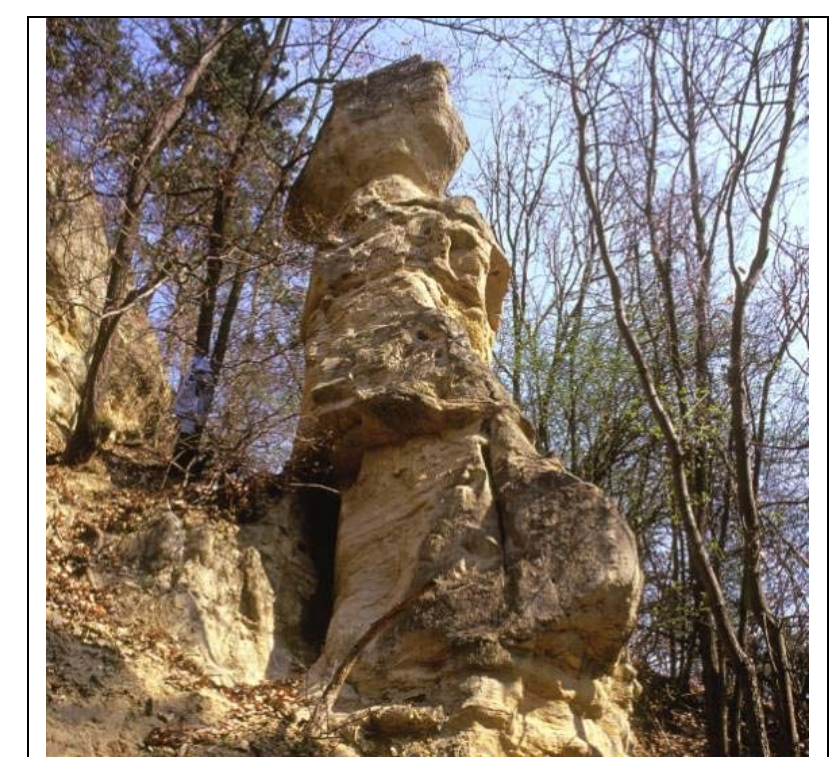

Fig 10. Girls's Stone, an interesting sandstone "hoodoo," close to village Nemti (Hungary). Photo: Karancsi, Z.

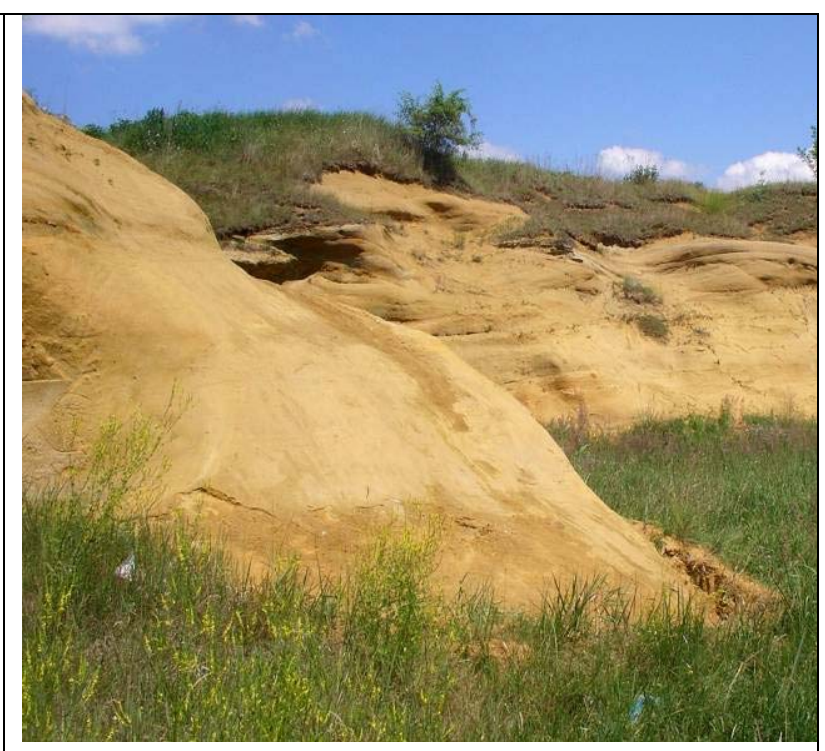

Fig 11. Sandstone walls at Csákányháza (Čakanovce, Slovakia). Photo: Gaál, L.

The region has some curiosities, as well, like the world-unique prismatic jointing of curved columns on andesites (Figure 16), a gas-bubble basalt lava cave of Kis-kö (Figure 17), the Cave of Mucsény (Mučín) formed by the mouldering of a tree trunk in rhyodacite tuff and especially the 'prehistoric Pompeii' at Ipolytarnóc, which has already won a European Diploma. In the latter geosite completely undamaged petrified footprints of extinct Miocene animals (rhinos, birds, carnivores, deer-like beasts, etc.) remained on the surface due to the sizable debris of a pyroclastic flow that had once buried the extinct habitat. Another curiosity is a collapsed basalt sheet on Szilvás-kő; brown-coal strata were lying under the basalt sheet, and because of undermining, unique deep chasms and pseudo-caves came into being. Also part of the geoheritage are the shafts and quarries of the abandoned mines, for especially coal- and basalt-mining was considerable, and in the centre of Salgótarján city an Underground Mining Museum can be visited in a former coal-mine. Mining heritage is also a good destination for eco- and geotourism (Dávid \& Karancsi 2010, Horváth \& Csüllög 2012).

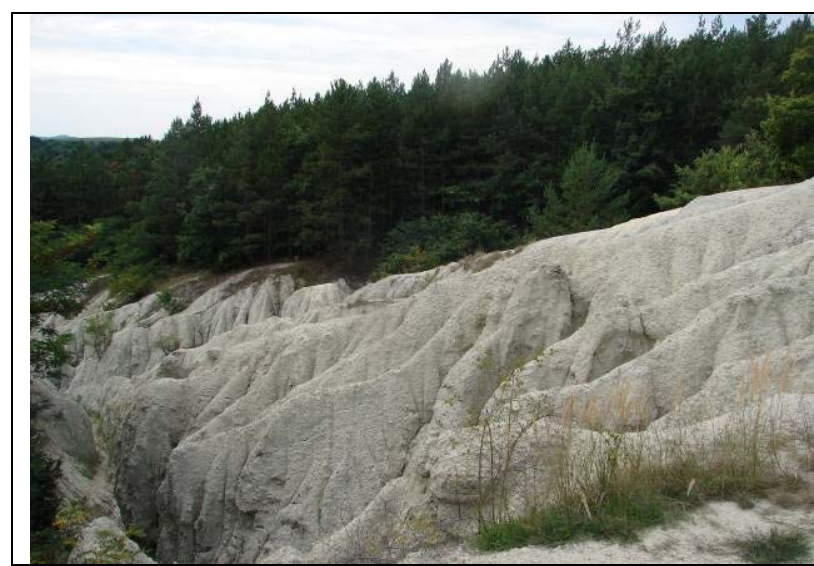

Fig 12. "Badland" on rhyolite tuff, close to village Kazár (Hungary). Photo: Karancsi, Z.

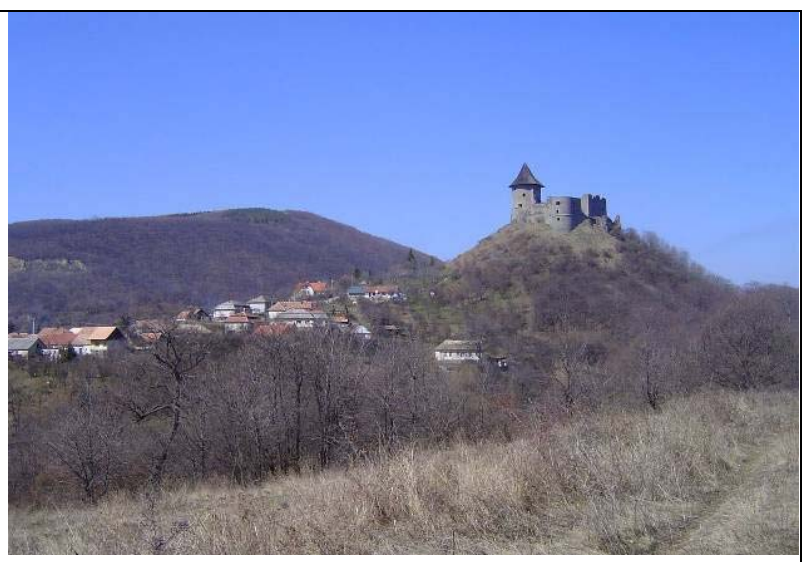

Fig 13. Basalt neck of Somos-kő (Šomoška, Slovakia) and Medves Plateau (Hungary-Slovakia). Photo: Horváth, G. 


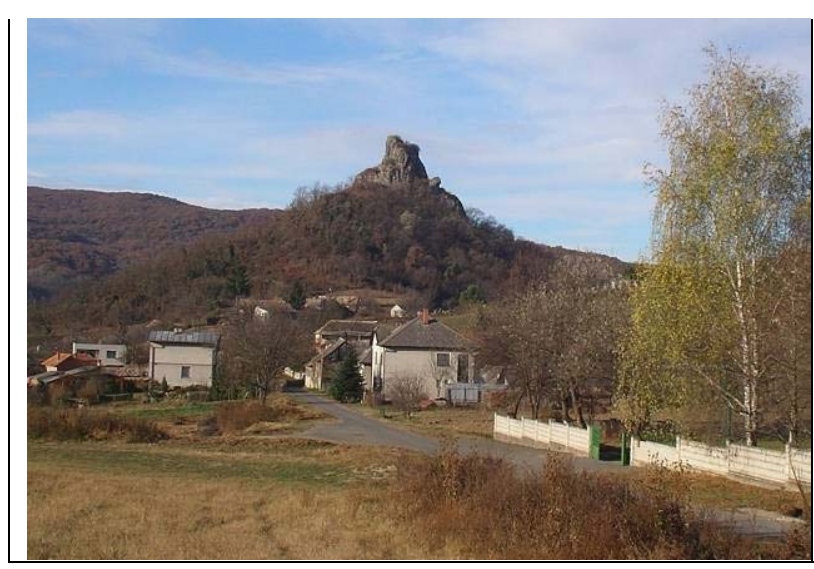

Fig 14. Basalt neck of Ajnács-kő (Hajnačka, Slovakia). Photo: Gaál, L.

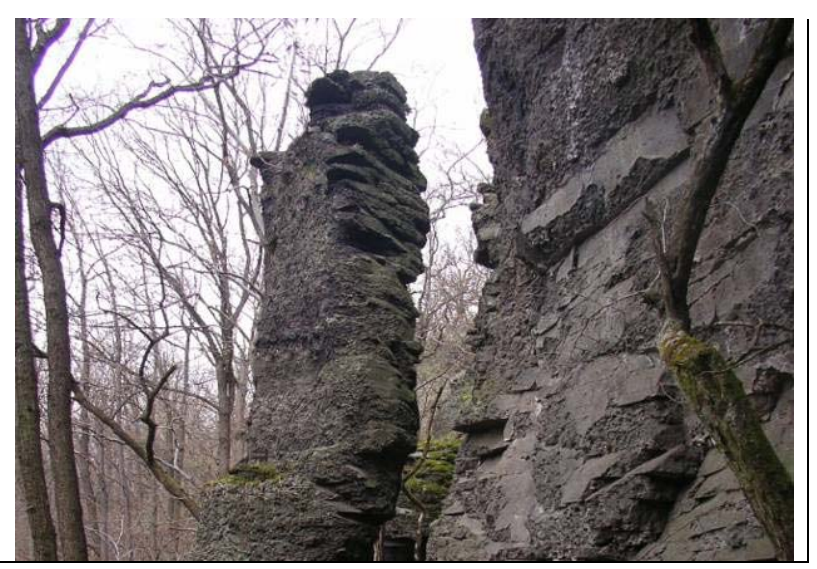

Fig 15. Basalt rocks of Béna-hegy (Belina, Slovakia). Photo: Gaál, L.

This region has a rich cultural heritage, as well. Archaeological finds, medieval castles and churches, sacral places, memorials to outstanding persons, museums, and exhibitions belong to this heritage. The region is the habitat of the so-called 'Palóc' (Palots) ethnic group, which has special folk art and living traditions. Hollókő village - part of the geopark - is a beautiful example of the Palóc folk architecture, is also famous for its traditional costumes and tools, and therefore can be found on the List of World Heritage. Cultural heritage is very important because only the geoheritage itself would not be enough to boost tourism as the major segment of the planned spatial development.

\section{Joint Hungarian-Slovakian organization of the geopark}

According to the Application dossier, 'The leader organization is the Committee of the Novohrad-Nógrád Geopark. Each side delegates four members for the term of four years to the Committee, which is headed by a president and will employ a voting system requiring a twothirds majority. There are experts working for the Committee who may represent the Geopark during local and international consultations.' This Hungarian-Slovakian joint operative board makes common decisions on tasks of development.

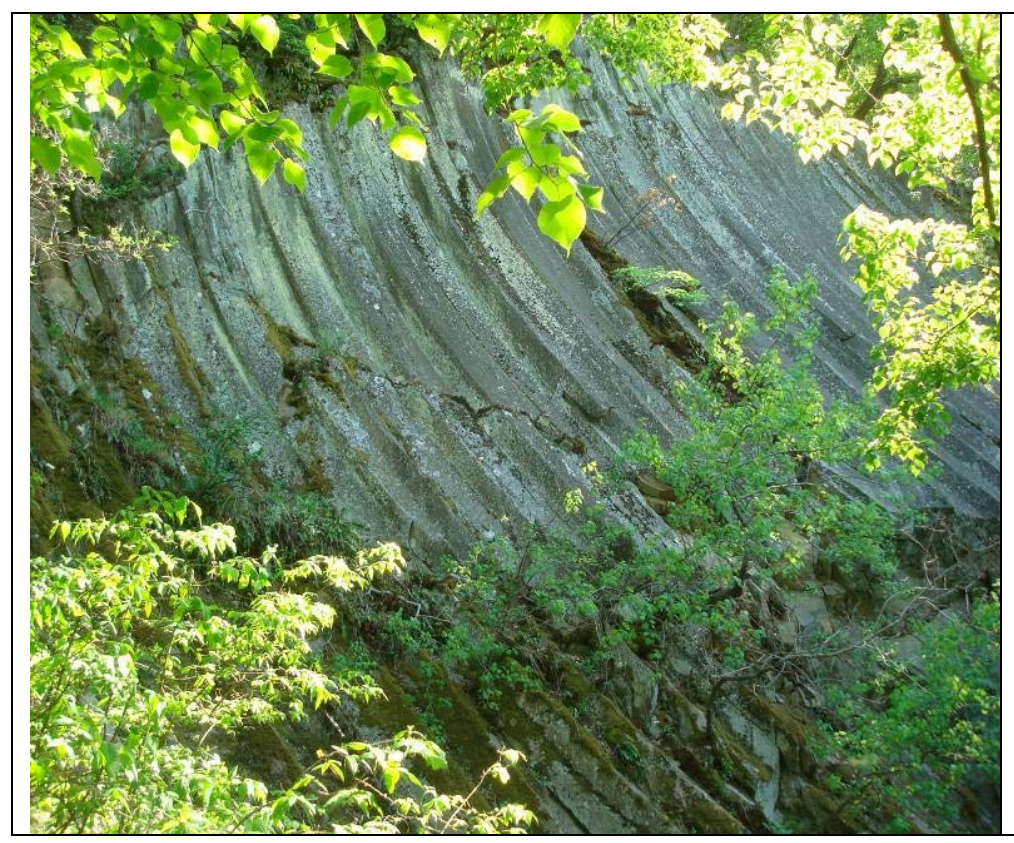

Fig 16. Curved columns on andesite, close to village Bér (Hungary). Photo: Horváth, G.

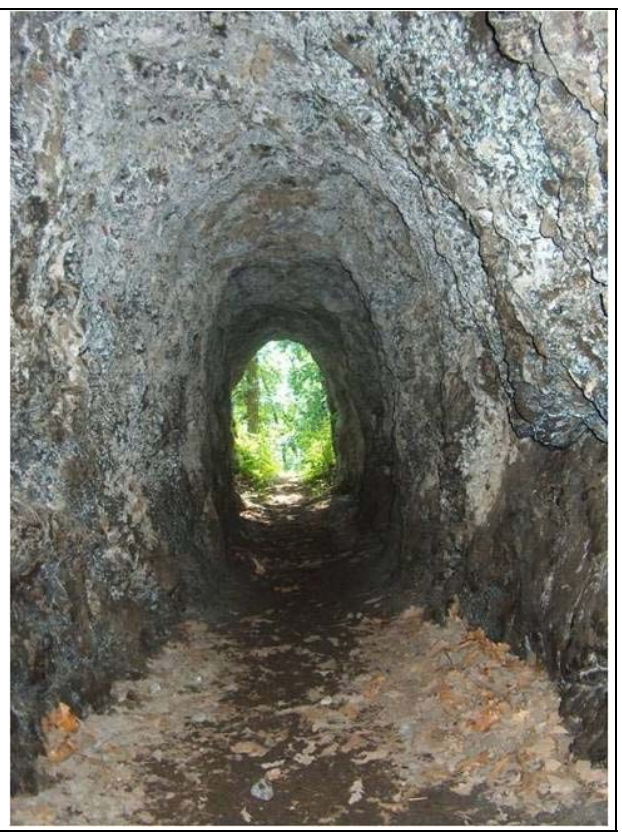

Fig 17. Bubble Cave of Kis-kö, close to village Szilaspogony (Hungary). Photo Karancsi, Z. 
Beyond this, there are other organizations on both sides. In Slovakia, two of them are worth mentioning: the main office is the Novohrad Tourist Information Centre, located in Filakovo (Fülek) and run by the municipality, which delegates one member to the Committee; and the autonomous organization of Geopark Novohrad-Nógrád Association, which is independent of the state institutions and delegates three members to the Committee, and its aim is to promote co-operation among different partners in the field of geotourism. Two organizations are important in Hungary as well; one of them, the Nógrád Geopark Nonprofit Ltd, located in Salgótarján, was founded to promote the activity of private investors and to control the administrative work of the geopark; its director is delegated to the Committee. The other one, the Nógrád Geopark Association represents state officials (e.g., Bükk National Park Directorate), state and private tourism organizations, non-governmental organizations (NGOs), universities, and individuals who intend to work for the benefit of the geopark; it delegates three members to the Committee. The Association maintains close ties with its Slovakian partner and leads widespread consultations among governmental and private entities.

These organizations can work successfully if both the Slovakian and Hungarian sides are ready to run jointly. Execution of projects in the framework of the geopark demands continuous cooperation between the governmental and local authorities and NGOs of both sides, and moreover drives the institutions involved into keeping tight contact and working together. Of course, different financial interests can cause contrary effects in the short term, however, generally the forcing power for the co-operation promotes improvements as if a hook at the connection of the two neighbouring countries.

\section{Executed measures}

Since the establishment of the geopark, some measures have taken place, especially for improving information, which is the key segment for increasing interest and by that contributing for maintaining the geopark. For creating a uniform image, trilingual (Slovakian, Hungarian, English) information tables, leaflets, and booklets in similar design were made and displayed. Organization of geotourism needs tight co-operation between tourism agencies; touristdestination management organizations (TDMs) were established on both sides to prepare and also execute cross-border projects, including the visiting of the geosites and the cultural sites of the geopark. Building a trilingual website of the geopark (www.nogradgeopark.eu) is in progress, and also another website, that of the Novohrad-Nógrád European Grouping of Territorial Cooperation with Limited Liability (www.nnegtc.eu/index.php/en/documents, mostly in English) contains information concerning the geopark. The trilingual website of the geopark informs about programs also in the other countries and occasionally also the TDM's website. For visitors who are more deeply interested in becoming acquainted with the geosites and cultural sites, the Novohrad-Nógrád Geopark Application dossier (full material with enclosures in pdf-form) is available and downloadable in English; Enclosure 5-6 (Geology I-II) contains all information regarding the geosites.

As has been mentioned, according to their definition by UNESCO, geoparks play important roles in education as well. All geoparks are excellent media for becoming acquainted with geoscientific and environmental knowledge, which can be studied on the spot. For the realization of these purposes, the information tables, leaflets, and booklets play significant roles. The official centre of the geopark can be found at the Ipolytarnóc Fossil Site, of which the Visitor Centre's reshaped building is a good educational centre as well. In its excellent exhibition hall (Figure 18), the geological past is interpreted. The centre has also an auditorium where lectures and conferences can be held. A very attractive program is to visit the Movie Theatre, in which a state-of-the-art, 4D film makes the visitor acquainted with prehistoric events. These attractions are completed by a study-trail network, consisting of five trails, from which the Geological Study-trail - because of its strict protection - can be visited only by interpreted, guided tours. 


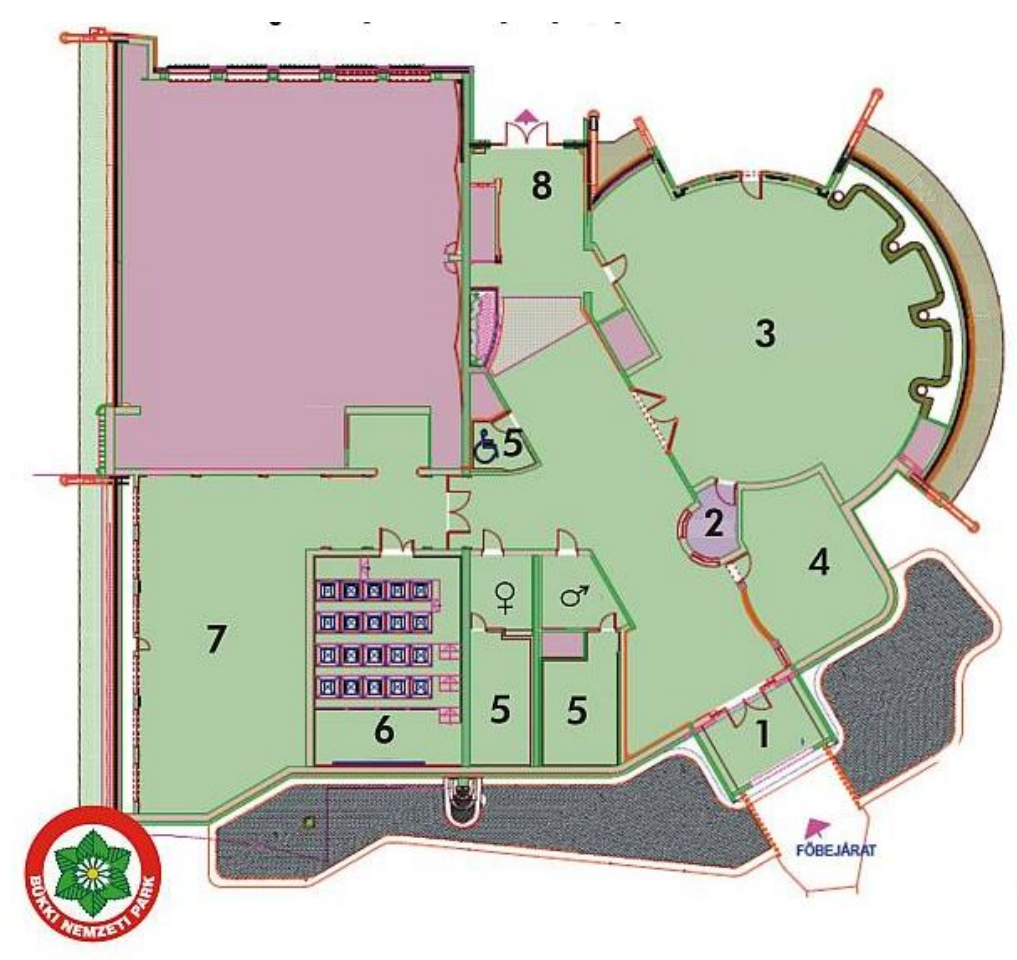

Fig 18. Map of the Visitor Centre. Source: http://osmaradvanyok.hu/index.php?p=visitor-centre. Legend: 1 Entrance, 2 - Ticket office, 3 - Information, 4-Gift shop, 5-WC, 6-4D Movie, 7 - Exhibition, 8 - Exit.

The new Baglyas-kő Visitor Centre has been another excellent institution for educational purposes since 2011. In this building excellent information boards reveal the main values of the geopark, including the geological, ecological, historical and cultural values of the region. The exhibition is related to a trip to the basalt butte of Baglyas-kő nature conservation area, which can be visited during opening hours at no charge. Also this building has a movie hall where excellent DVDs can be seen also showing the positive values (geosites, plant and animal kingdom, etc.) of the geopark.

Also other - mostly educational - materials are available on the Internet describing geologicalgeomorphologic curiosities of the region (made among others by Harangi, $S$ 2010; in Hungarian) ${ }^{3}$.

\section{Requirements and perspectives}

The geoheritage together with the cultural heritage affords great opportunity for tourism development. However, there are still no satisfactory outcomes, and there are still great prospects for cooperation, taking into consideration that the geo-sites should be thoroughly introduced, especially in the other country, and should be supplied with appropriate infrastructure. It should also be made known via the tools of the modern media. Study trails, interpretive centres, more information and orientation tables, and leaflets need to be created (in the area of the Geopark there are already 23 study trails, but only two of them cross the border). Car parks, comfortable paths and cycling trails - also across the borderline - need to be built; public transport has to be improved and joined as well (especially this factor would require and deserve much more care). The fulfilment of these tasks is still at an initial stage. The capacity of geotourism is only partly utilized, so it should be increased, while cultural events should be more frequent and effective, and attractiveness should be strengthened. For these purposes cooperation between the self-governing and local authorities should be more fluent and smooth, local TDMs should work much effectively together, and jealousies between private interests should be much more reduced. Very important is that other new innovative ideas should be

\footnotetext{
${ }^{3}$ available http://www.nogradgeopark.eu/index.php?f=2\&s=7\&nid=436). Slovakian translations of these materials are in progress.
} 
involved and applied. From the point of view of the spatial development of the micro regions with the fulfilment of the above mentioned task, many more new jobs will be created.

In 2012, a positive decision resulted in creating a good opportunity for the development of the Geopark. The Novohrad-Nógrád Geopark Nonprofit, Ltd., and the Self-government of County Rank Town Salgótarján sent in a joint application within the framework of the Operative Development Programs for North Hungary (financed mostly by EU funds), and it was a very successful application because 614,000,000 HUF (about 2,193,000 EUR) has been obtained for developing the tourism of the Geopark. Although it is only available for the Hungarian side, it also helps in executing common plans. It is very important because, taking into consideration both perspectives and threats, it should be known that the title 'geopark' will be revised after a five-year functioning, and, in the worst case, the title can be withdrawn. Therefore, for the progress of the Nógrád-Novohrad Geopark, great effort is necessary, and it requires better utilization of the possibilities of Slovakian-Hungarian co-operation, as well.

It would be a sin not to take full advantage of such an excellent cross-border co-operation.

\section{Acknowledgement}

The publishing of the paper is supported by the Visegrad Fund, project Nr. 11220149 "Borders and Borderlands within the Central Europe".

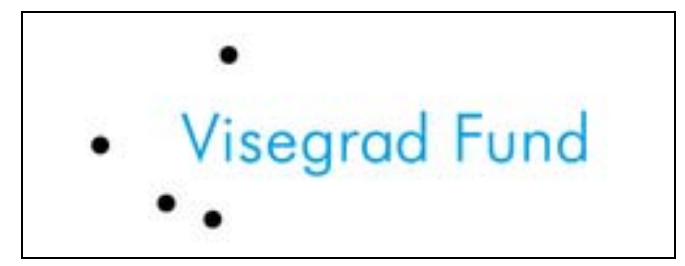

References

[1] Application dossier for nomination as a European Geopark. - In: http://www.nogradgeopark.eu/doc/NNG_Application_s_.pdf. 39 p.

[2] Cimermanová, I. \& Anderková, E. (2006). 'Getting through the country of youngest volcanoes' - The Novohrad-Nógrád Geopark. In GeoTour 2006 Conference, http://www.kgptour.tuke.sk/conferences_soubory/pdf\%207\%202\%2007/8_5_cimermanova, anderkova\%206.pdf. 8 p.

[3] Csüllög, G. (2002). The revaluation of border regions in the changing spatial structure (pp. 69-79). In: Süli-Zakar I., ed., Borders and cross-border co-operations in the Central European transformation countries. Debrecen: Debreceni Egyetem.

[4] Csüllög, G. (2003). The changes of the spatial structure in the Carpathian Basin (pp. 2025). In Vaishar, A., Zapletalova, J. \& Munzar, J., eds.: Regional geography and its applications. Brno: Institute of Geonics, Academy of Sciences of the Czech Republic.

[5] Csüllög, G. (2008). The role of borders in spatial structure changes (pp. 13-18). In SüliZakar, I., eds., Neighbours and partners: On the two side of the border. Debrecen: Debreceni Egyetem Kossuth Egyetemi kiadó.

[6] Dávid, L. \& Karancsi, Z. (2010). Quarrying, geoheritages and tourism development in the Medves region along the Hungarian-Slovakian border. - Acta Geoturistica 1(1), 1-11.

[7] Dowling, R. K. \& Newsome, D., eds. (2006). Geotourism. Oxford: Elsevier ButterworthHeinemann.

[8] Dowling, R. K. (2011). Geotourism's Global Growth. Geoheritage 3(1), 1-13. 
[9] Európai Unió: Magyarország-Szlovákia Határon Átnyúló Együttmüködési Program 2007 2013. Available at: www.husk-cbc.eu.

[10] European Commission: Operational programme 'Hungary-Slovak Republic'. Available at: http://ec.europa.eu/regional_policy/country/prordn/details_new.cfm?LAN=7\&gv_PAY=HU\& gv_reg=ALL\&gv_PGM=1290\&gv_per=2\&gv_defL=7.

[11] Európska únia: Program cezhraničnej spolupráce Mad’arská republika - Slovenská republika 2007 - 2013. Available at: www.husk-cbc.eu/sk.

[12] Harangi, S. (2010). Menjünk kirándulni! Kazár badland. Available at: www.nngeopark.eu/openfile.php?dwnid=9\&t=1.

[13] Horváth, G. \& Csüllög, G. (2011). Geoconservation and geotourism in a new Central European geopark (pp. 31-42). In Lin, J-C. J., ed., Landscape Conservation. Taipei: National Taiwan University.

[14] Horváth, G. \& Csüllög, G. (2012). The role of ecotourism and geoheritage in the spatial development of former mining regions (pp. 226-240). In Wirth, P., Černič Mali, B., \& Fischer, W., eds., Post-mining regions in Central Europe. Problems, Potentials, Possibilities. München: Oekom Verlag.

[15] Hungary-Slovakia cross-border co-operation programme 2007-2013 (2007). Available at: http://www.nfu.hu/download/4919/Hungary-Slovakia\%20Cross-border\%20Cooperation\%20Programme20071114.pdf.

[16] Novohrad-Nógrád European Grouping of Territorial Cooperation with Limited Liability. Available at: http://www.nnegtc.eu/.

[17] Novohrad-Nógrád Geopark: Master plan 2010-2015. Available at: http://www.petrifiedforest.gr/NEW\%20pf/25th\%20European\%20Geoparks\%20Meeting\%20 2010\%20\%E2\%80\%93\%20Luberon\%20Geopark/Novohrad\%20\%20Nograd\%20Geopark/2\%20NNG_masterplan_2010_2015.pdf.

[18] Pralong, J-P. (2006). Geotourism: A new form of tourism utilising natural landscapes and based on imagination and emotion. Tourism Review 61(3), 20-25. Doi: 10.1108/eb058476.

[19] Szarvas, I. (2009). The Novohrad-Nógrád Geopark. Available at: http://www.magyartelepulesek.hu/ipolytarnoc/nngeo.html.

[20] Szarvas, I. (2011). Role of Geoparks in education - the transborder Novohrad-Nógrád Geopark. Available at:

http://www.eurogeologists.de/images/content/geology_education_workshop/lmre_Szarvas. pdf.

[21] The Novohrad-Nógrád Geopark. Available at: http://osmaradvanyok.hu/index.php?p=geo park-2.

[22] UNESCO (2010). Guidelines and Criteria for National Geoparks seeking UNESCO's assistance to join the Global Geoparks Network (GGN). Available at: http://www.unesco.org/new/fileadmin/MULTIMEDIA/HQ/SC/pdf/sc_geoparcs_2010guidelin es.pdf.

[23] UNESCO (2010). The Langkawi Declaration. Available at: http://www.docstoc.com/docs/ 136027347/The-Langkawi-Declaration. 